NBER WORKING PAPER SERIES

BANK PORTFOLIO CHOICE WITH PRIVATE INFORMATION ABOUT LOAN QUALITY:

THEORY AND IMPLICATIONS

FOR REGULATION

Deborah Lucas

Robert L. McDonald

Working Paper No. 2421

NATIONAL BUREAU OF ECONOMIC RESEARCH

1050 Massachusetts Avenue

Cambridge, MA 02138

October 1987

We would like to thank Gary Gorton, Stuart Greenbaum, Joe Haubrich, George Pennachi, Anjan Thakor, seminar participants at Baruch College and Wharton, and participants at the Conference on Asset Securitization and Off-Balance-Sheet Financing, held at Northwestern University, for helpful suggestions and comments. We retain responsibility for errors and omissions. The research reported here is part of the NBER's research program in Financial Markets and Monetary Economics. Any opinions expressed are those of the authors and not those of the National Bureau of Economic Research. 
NBER Working Paper \#2421

October 1987

\section{Bank Portfolio Choice with Private Information About Loan Quality: \\ Theory and Implications for Regulation}

\section{$\underline{\text { ABSTRACT }}$}

This paper models bank asset choice when shareholders know more about loan quality than do outsiders. Because of this informational asymmetry, the price of loans in the secondary market is the price for poor quality loans. Banks desire to hold marketable securities in order to avoid liquidating good quality loans at the "lemons" price, but also have a countervailing desire to hold risky loans in order to maximize the value of deposit insurance. In this context, portfolio composition and bank safety is examined as a function of the market distribution of loan quality, and the distribution of deposits. The model suggests that off-balance sheet commitments have little effect on bankruptcy risk, and induce banks to hold more securities. We also show that an increase in the bank equity requirement will unambiguously increase bank safety in the long run. In the short run, banks are unambiguously riskier on-balance-sheet, although the effect on bank safety is ambiguous.

Deborah Lucas

Finance Department

Kellogg School

Northwestern University

Evanston, IL 60201

(312) 491-8333
Robert McDonald

Finance Department

Kellogg School

Northwestern University

Evanston, IL 60201

(312) 491-8344 


\section{Introduction}

The ability to design effective bank regulations depends critically on understanding the asset allocation decisions of banks. For example, whether an increase in the bank capital requirement increases or reduces bankruptcy risk affects the desirability of using capital requirements as a policy tool. Another important question is how off-balance-sheet items such as lines of credit and loan commitments will affect a bank's portfolio decision. To address questions such as these, we develop a model of the banking firm which focuses on bank asset decisions.

There are two driving forces behind a bank's choice between risky loans and securities in the model: a) banks want to hold risky loans to maximize the value of FDIC insurance; and b) because banks have private information about risky loans ex post, most loans cannot be sold at a fair price when a need for cash arises. Thus banks choose to hold a portion of their portfolio in securities about which there is symmetric information, because these securities can be sold at a fair price.

Many theories of bank portfolio choice generate a demand for relatively risk-free securities in the presence of FDIC insurance by assuming that banks are run by risk-averse managers or owners. This explanation has been suggested by Pyle (1981), Hart and Jaffee (1974) and Koehn and Santomero (1980), among others, who explain bank portfolio choice under the assumption that bank managers choose mean-variance efficient portfolios. Empirical evidence, however, points against these models: the risky portion of bank portfolios is relatively undiversified, with banks often specializing in loans to a particular industry or locality. More fundamentally, as long as the bank is owned by investors who can diversify on their own account, it 
will be suboptimal for the bank to diversify, thereby lowering the value of FDIC insurance. In contrast, we assume that banks are risk-neutral. This implies that banks have no intrinsic incentive to diversify their risky assets. Nevertheless, banks choose to hold marketable securities in order to avoid loan sales at an unfavorable price. ${ }^{1}$

Banks may need to sell loans because they face stochastic external sources of demand for cash: two examples of such external demands are deposit withdrawals and loan commitments. Insured deposit withdrawals are treated as an exogenous and stochastic source of liquidity demand. Although banks have some discretion about honoring loan commitments and other offbalance sheet sources of liquidity demand, these commitments can lead to a large and immediate need for cash. Since off-balance-sheet commitments are a significant fraction of bank assets, in practice they may be a major source of variation in cash demand. The model enables us to estimate a usuallyignored component of the cost to the bank of making such commitments.

The effect of a change in capital requirements on asset risk is explored in both the short and long-run. In the long-run, increasing the equity requirement significantly lowers bankruptcy risk. The optimal mix between securities and loans is largely unaffected. The short-run effects are more complex. A small increase in the equity requirement tends to reduce bankruptcy risk, while a large increase in the equity requirement can increase bankruptcy risk. ${ }^{2}$ The increase also has the perverse effect of making banks appear riskier on balance sheet.

Our argument for the existence of liquidity costs may be outlined simply: if banks know more about loan quality than do outsiders, and if outsiders are aware of this, then there will be a "lemons market" (Akerlof, 
1970) for loans. Equilibrium secondary loan prices will therefore reflect the price of below-average quality loans, and banks will try to reduce the probability of having to sell loans. One way for banks to avoid selling loans is to hold securities about which there is symmetric information (and which therefore bear no lemons discount), such as Treasury bills. Thus, our model suggests a structural explanation for the existence and magnitude of liquidity costs in selling risky assets. This contrasts with the sizable literature that takes these costs as exogenous (e.g., Poole (1968), Frost (1971), Baltensperger (1974), and Sprenkle (1985)).

The paper is organized as follows: In Section 2 we discuss how asymmetric information leads to a "lemons" discount. Section 3 presents the model, and in Section 4 conditions are derived that determine the bank's optimal portfolio. The sensitivity of portfolio composition to changes in loan return variability, deposit variability, and liquidation penalty is demonstrated by simulation in Section 5. Section 6 argues that loan commitments are equivalent to stochastic deposit withdrawals, and so can be expected to increase the demand for securities. Section 7 discusses the effect of changing equity requirements.

\section{Lemons and the Market for Loans}

We assume that ex post banks know the quality of loans on their books and potential buyers do not. The market is competitive, so that there are a large number of potential buyers who can either buy or refuse to buy a loan at the price offered by the bank. Suppose that buyers are willing to buy a 
used loans at a price reflecting the average quality of loans ex ante. In this case banks with average quality loans will be indifferent between selling them or keeping them, since the price will be fair. However, no bank with a higher quality loan will voluntarily sell at the price appropriate to an average quality loan, since doing so would mean incurring a loss. At the same time, all banks with below-average quality loans will profitably sell their loans at the average-quality loan price. Thus, buyers of loans will on average pay too high a price, and loans will be priced to reflect belowaverage quality. This argument, made originally in a different context by Akerlof (1970), can be used to show that in the absence of forced loan sales, the equilibrium price of loans will be the price appropriate for the minimum quality loan. In particular, for the investor to receive the average rate of return when loan quality is $\alpha_{L}$, the discount $c$ is given by solving $(1-c)(1+r)$ $=\left(1+\alpha_{L}\right)$. The wider the dispersion between high and low quality loans, the greater will be the banks' desire to avoid bearing this cost. Thus by endogenizing the cost of selling loans, we will be able to predict the sensitivity of portfolio choice to changes in the riskiness of the environment.

When there are forced sales of some high quality loans for liquidity, the equilibrium price of a used loan will not be the price of the minimum quality loan. Rather, the equilibrium price will reflect both the average quality of loans sold due to forced liquidations and those sold because their quality was worse than that reflected in the secondary market price. Thus, the discount $c$ derived above is an upper bound for the true discount on a used loan. Even with forced liquidations, it is clear that the equilibrium price of loans will be below that of the average loan, and thus there will be 
an incentive for banks to hold marketable securities to reduce the possibility of a forced loan sale. The simulations in Section 5 illustrate the effect of varying the discount c on portfolio composition.

An alternative to selling loans is issuing securities; we assume in this paper that firms issue no securities. This is a strong assumption, particularly in light of the frequency with which banks issue uninsured debt. The sale of risky debt or equity, however, is similar to the direct sale of a loan since the price a bank outsider will pay for debt or equity depends on loan quality. Lucas and McDonald (1987) show that the information asymmetry leads to higher priced uninsured debt than when there is symmetric information, so that even with funding alternatives such as debt issues, banks will still face a potential lemons cost. A similar point is made by Myers and Majluf (1984). Here we take the liability structure as fixed to simplify the analysis.

Finally, we also rule out borrowing from the discount window as a source of funds. If by borrowing from the discount window banks could costlessly avoid all loan sales for liquidity purposes, then there would be no motivation for holding securities in this model. However, there is not unlimited access to the discount window, and such borrowing is not costless. Inclusion of the discount window in the model would likely reduce estimates of bank security holdings, ${ }^{3}$ but qualitatively leave the results unchanged.

\section{The Model}

We look at the problem of bank asset choice for a bank facing two sources of uncertainty: risky returns on loans and random deposit realizations. The bank must choose the percentage of assets held as loans 
and the percentage held as securities.

A security is defined to be a low-risk asset for which there is no private information, while loans are risky assets about which banks have private information. The underlying idea is that banks learn about the quality of loans that they make, both from an initial investment in information and over time. Thus, a loan made to IBM might be considered a security under our definition. We assume that securities have relatively low risk. This is a critical assumption; if assets with symmetric information are riskier than loans, loans will be dominated. In practice, banks are prohibited from holding risky, publicly-valued assets such as stocks, while banks do hold a significant fraction of their portfolio in relatively lowrisk government securities.

The bank operates for three periods. In the first period all banks are identical, while in the second period their actions depend on their realization of loan quality and deposits. In the final period the bank is dissolved. We begin by describing the cash flows, decision variables and constraints in each period. This constrained optimization problem will then be solved in Section 4. Because of the interaction between FDIC insurance, the equity requirement, and the realizations of deposits and loan quality, the model is quite complex. The simulation results and accompanying explanations presented in Section 5 should allow the reader to understand the model without working through the detail of the next two sections.

The cash flows, decision variables, and constraints in each period are as follows:

a) Period 0

The bank starts with an exogenous, insured deposit inflow D. The 
capital requirement is a fraction $g$ of deposits, implying that initial equity must be at least gD. Investments can be made in new loans and securities. Thus equity and deposits must be divided between loans, $\mathrm{L}_{0}$, and securities, $\mathrm{S}_{0}$. Equity reduces the value of FDIC insurance, so we assume that initially, equity will equal the legal minimum:

$$
D(1+g)=S_{0}+L_{0}
$$

Since equity makes up the difference between assets and deposits, the net cash flow for equity holders at time 0 is $-g D$

Investments in securities and loans last for two periods. Securities earn the risk-free rate $r$ in both period 1 and period 2. Loans, on the other hand, are risky. In period 1 , loans pay a certain return of $\alpha_{1}>r .^{4}$ In period 2 they return $\alpha_{2}$, which is distributed over $\left[\alpha_{L}, \alpha_{H}\right]$, with expected value equal to the risk-free rate $r$.

b) Period 1:

Between period 0 and period 1 , the bank receives two new pieces of information. First, the bank learns the quality of period 0 loans, so uncertainty is resolved about $\alpha_{2}$, the period 2 return on loans bought in period 0. 5 After loan quality is known, in period 1 the bank learns its deposit realization $\delta$. A positive $\delta$ is a withdrawal, and a negative $\delta$ is a deposit. $\delta$ is distributed on $\left[\delta_{L}, \delta_{H}\right]$. The bank must return any deposits demanded, but may decline to take new deposits. The amount of deposits voluntarily turned away is denoted $\delta_{v}$. We will see later that deposits may be turned away when a bank anticipates bankruptcy in the next period. 
Given the realizations of $\alpha$ and $\delta$, the bank must decide the following: whether to remain in husinace or on hankeunt

(5) $\max \left[0,\left(\mathrm{~S}_{0}-\Delta \mathrm{S}_{0}\right)(1+\mathrm{r})+\left(\mathrm{L}_{0}-\Delta \mathrm{L}_{0}\right)\left(1+\alpha_{2}\right)+\mathrm{L}_{1}\left(1+\alpha_{2}^{\prime}\right)+\mathrm{S}_{1}(1+\mathrm{r})\right.$

$\left.-\left(D-\delta-\delta_{v}\right)(1+r)\right]$

\section{Choosing the Optimal Portfolio}

The objective of the bank is to maximize the present value of expected cash flows. Since the bank is risk neutral, it discounts cash flows at the risk-free rate, with discount factor $\beta=1 /(1+r)$. The bank's time 0 choice of $\mathrm{S}_{0}$ and $\mathrm{L}_{0}$ will be influenced by what it expects will occur in periods 1 and 2. In this section the allocation problem is solved via dynamic programming.

\section{$\underline{\text { Period } 2}$}

Since all uncertainty has been resolved and no choices remain, equation (5) describes the bank's profits.

\section{Period 1}

At time 1 , the bank knows $\mathrm{S}_{0}, \mathrm{~L}_{0}, \alpha_{2}$, and $\delta$. The only remaining uncertainty is the return on new loans $\alpha_{2}^{\prime}$, if new loans are purchased. The bank chooses $\Delta \mathrm{S}_{0}, \Delta \mathrm{L}_{0}, \mathrm{~L}_{1}, \mathrm{~S}_{1}$ and $\delta_{\mathrm{v}}$ to maximize

$$
\mathrm{rS}_{0}+\Delta \mathrm{S}_{0}+\alpha_{1} \mathrm{~L}_{0}+\Delta \mathrm{L}_{0}(1-\mathrm{c})-\mathrm{rD}-\delta_{\mathrm{v}}-\delta_{1}-\mathrm{L}_{1}-\mathrm{S}_{1}+
$$

$$
\begin{array}{r}
\beta \int_{\hat{\alpha}}^{\alpha}\left[\left(\mathrm{S}_{0}-\Delta \mathrm{S}_{0}\right)(1+\mathrm{r})+\left(\mathrm{L}_{0}-\Delta \mathrm{L}_{0}\right)\left(1+\alpha_{2}\right)+\mathrm{L}_{1}\left(1+\alpha_{2}^{\prime}\right)+\mathrm{S}_{1}(1+\mathrm{r})\right. \\
\left.-\left(\mathrm{D}-\delta-\delta_{\mathrm{v}}\right)(1+\mathrm{r})\right] \mathrm{f}\left(\alpha_{2}^{\prime}\right) \mathrm{d} \alpha_{2}^{\prime}
\end{array}
$$

subject to eqs. (3) and (4), and where $\hat{\alpha}$ is the minimum return on $L_{1}$ in 
period 2. Thus, $\hat{\alpha}=\alpha_{H}$ if period 2 profits are negative, i.e. the bank will be bankrupt, and $\hat{\alpha}=\alpha_{L}$ if period 2 profits are positive, i.e. the bank will be solvent.)

Lemmas 1 through 5 characterize the bank's actions as a function of the state variables. First, lemmas 1 and 2 (proved in Appendix A) describe the bank's security choices in period 1.

Lemma 1. No new securities are purchased in period $1: S_{1}=0$.

Lemma 2. All period zero securities are liquidated in period 1: $\Delta \mathrm{S}_{0}=\mathrm{S}_{0}$

These lemmas can be explained intuitively. The bank prefers securities to loans only when securities provide a buffer against liquidation costs. Otherwise loans are more valuable because their variance increases the value of FDIC insurance. After the realization of $\delta$ is known, there will be no more liquidation costs and hence no more demand for securities. In a version of the model with a longer horizon, securities would be valuable in all but the penultimate period. For this reason, time 0 security holdings, rather than time 1 security holdings, are of predictive interest in this model. Bank decisions concerning loans, dividends, and deposits are described by Lemmas 3 through 5 . Optimal actions depend on the realizations of withdrawals and the quality of loans made at time 0 . The basic idea is that if a bank anticipates bankruptcy at time 2, the equity holders want to pay themselves as large a dividend as possible at time 1 , since they expect low returns from investing in new loans. On the other hand, if time 0 loans are sufficiently good, banks will prefer to use new deposits to buy new loans, because of the positive value of FDIC insurance. 
Changes in deposits can be divided into three regions, illustrated schematically in Figure 1 . In Region 1 , the period 1 withdrawal is sufficiently large so that period 0 loans must be liquidated, but not large enough to force the bank out of business. The minimum withdrawal that forces the bank out of business, $\delta^{b}$, is the withdrawal that forces violation of (3) or (4). This reduces to ${ }^{6}$

(7) $\delta^{\mathrm{b}}=\min \left[\mathrm{s}_{0}(1+\mathrm{r})+\mathrm{L}_{0} \alpha_{1}+(1-\mathrm{c}) \mathrm{L}_{0}-\mathrm{rD}\right.$,

$$
\left.\frac{\left(1-c+\alpha_{1}\right) L_{0}+(1+r) S_{0}-(r+(1-c)(1+g)) D}{1-(1+g)(1-c)}\right]
$$

The minimum withdrawal to force liquidation, $\delta^{1}$, is defined by

$$
\delta^{1}=\mathrm{S}_{0}(1+r)+\alpha_{1} \mathrm{~L}_{0}-\mathrm{rD}
$$

In Region 2 no loans need be liquidated, but the withdrawal is large enough so that no new loans can be purchased except by foregoing a dividend and effectively adding equity to the firm. Region 2 is bounded below by $\mathrm{s}_{0} /(1+\mathrm{g})$, and above by $\delta^{1}$. Finally, in Region 3 , cash from the sale of securities and new deposits is enough to buy new loans without voluntarily adding equity to buy new loans. In this region withdrawals do not exceed $\mathrm{S}_{0} /(1+\mathrm{g})$, or there is a net deposit inflow. 


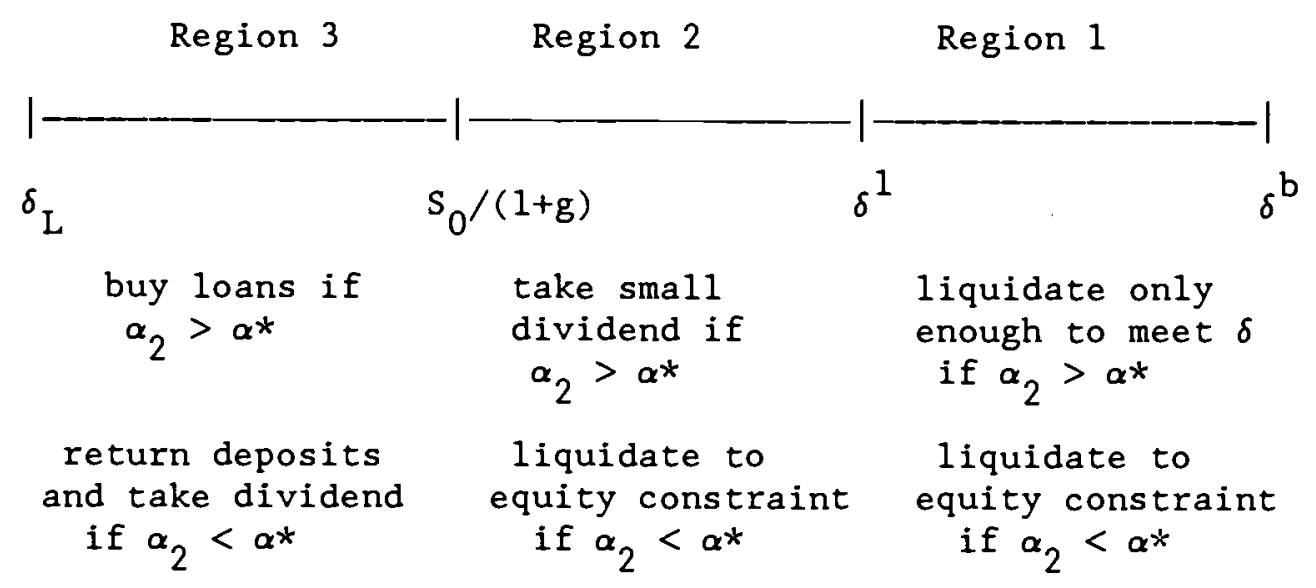

Figure 1. Optimal actions depend on deposit/withdrawal and loan quality

In each of these regions, there is a critical value of time 0 loan quality, $\alpha^{*}$, that determines the bank's best strategy. If $\alpha_{2}<\alpha^{*}$, the bank would rather pull out as much money as possible in period 1 in anticipation of low profits or bankruptcy the next period. Otherwise, the bank prefers to stay in business and purchase as many new loans as possible up to the point where the equity constraint is binding. $\alpha^{*}$ is the loan quality at which shareholders are indifferent between 1 iquidating the bank and operating it for one more period. Assuming $(1+g)(1-c)<1,{ }^{7}$ for all regions $\alpha *$ can be shown to solve (this follows from the proofs of Lemmas $3-5$ in the appendix): 
(9)

$$
\begin{aligned}
& {\left[\mathrm{L}_{0}-\left(\mathrm{D}-\max \left[\mathrm{S}_{0} /(1+\mathrm{g}), \delta\right]\right)(1+\mathrm{g})\right](1-\mathrm{C})-} \\
& \max \left[\mathrm{s}_{0} /(1+\mathrm{g}), \delta\right]+\max \left[\mathrm{s}_{0} /(1+\mathrm{g})-\delta, 0\right](1+\mathrm{g})+\delta- \\
& \max \left[\delta-\mathrm{S}_{0}(1+r)-\alpha_{1} \mathrm{~L}_{0}+\mathrm{rD}, 0\right] \\
& \beta \int_{\hat{\alpha}}^{\alpha}\left\{L_{0}\left(1+\alpha^{*}\right)-\max \left[\delta-\mathrm{S}_{0}(1+\mathrm{r})-\mathrm{L}_{0} \alpha_{1}+\mathrm{rD}, 0 \frac{]\left(1+\alpha^{*}\right)+}{(1-\mathrm{c})}+\right.\right. \\
& \left.\max \left[S_{0} /(1+g)-\delta, 0\right](1+g)\left(1+\alpha_{2}^{\prime}\right)-(1+r)(D-\delta)\right\} f\left(\alpha_{2}^{\prime}\right) \mathrm{d} \alpha_{2}^{\prime}
\end{aligned}
$$

The following lemmas describe a bank's behavior more precisely in each of these three regions, assuming that $(1+g)(1-c)<1$. Proofs are in Appendix A.

Lemma 3. In Region 1, for $\alpha_{2}>\alpha^{*}$, loan liquidations are at the minimum level allowing withdrawals to be paid:

$$
\Delta \mathrm{L}_{0}=\left(\delta-\mathrm{S}_{0}(1+\mathrm{r})-\alpha_{1} \mathrm{~L}_{0}+\mathrm{rD}\right) /(1-\mathrm{c}) \text {. }
$$

For $\alpha_{2}<\alpha^{*}$, loans are liquidated until the equity constraint is binding:

$$
\Delta \mathrm{L}_{0}=\mathrm{L}_{0}-[(\mathrm{D}-\delta)(1+\mathrm{g})] \text {. }
$$

$\delta_{\mathrm{v}}$ and $\mathrm{L}_{1}$ are zero in both cases.

Lemma 4. In Region 2, if $\alpha_{2}>\alpha *$ the bank pays $\delta$, pays a dividend with cash from net interest income, and liquidates no loans. If $\alpha_{2}<\alpha^{*}, \Delta \mathrm{L}_{0}=\mathrm{L}_{0}$ $[(D-\delta)(1+g)] . \quad L_{1}$ and $\delta_{v}$ are zero in both cases.

Lemma 5. In Region 3, if $\alpha_{2}>\alpha^{*}$, voluntary return of deposits $\delta_{v}$ is zero, 
and new loans $\mathrm{L}_{1}=\mathrm{S}_{0}-\delta(\mathrm{l}+\mathrm{g}) .^{8}$ If $\alpha_{2}<\alpha^{*}, \mathrm{~L}_{1}=0$, and assets are reduced until the equity constraint eq. (4) is binding. This implies a voluntary deposit return of $\delta_{\mathrm{v}}=\max \left(0, \mathrm{~s}_{0} /(1+\mathrm{g})-\delta\right)$.

Lemmas 3 to 5 summarize the bank's portfolio strategy in period 1. For high quality loans liquidation is avoided, and the bank makes the maximum possible additional investment in new loans with money from insured deposits. Low quality loans cause the bank to maximize current dividends in anticipation of a low return in the following period. Equity is kept to the legal minimum by dividend payments, except in the situation where paying a dividend would involve liquidation of sufficiently high quality loans. We can now identify two sources of benefit from holding securities. First, securities prevent the bank from having to liquidate high quality loans at a substantial penalty when the withdrawal realization is high. Second, a more subtle benefit is that when the bank has low quality loans, securities make it less costly to take out a larger dividend in period 1, in anticipation of bankruptcy in period 2 .

\section{$\underline{\text { Period } 0}$}

Finally, the period 0 maximization problem can be solved. The bank chooses $\mathrm{S}_{0}$ and $\mathrm{L}_{0}$ to maximize the present discounted value of future cash flows, subject to eq. (1). The initial equity investment, given in eq. (2), is not affected by the bank's actions. Taking into account optimal behavior in periods 1 and 2 as described by lemmas 1 to 5 , the value function $v_{0}$ can be written as a function of $S_{0}$ and $L_{0}$. The value function is given in Appendix B. 
If the value function is maximized at an interior $\mathrm{S}_{0}>0$, then the derivative of the value function with respect to $S_{0}$ will be zero at the maximum. Note that $\mathrm{L}_{0}$ can be replaced by $\mathrm{D}(1+\mathrm{g})-\mathrm{S}_{0}$ using (1), so the problem reduces to one choice variable. Then differentiating $v_{0}$ with respect to $s_{0}$ yields ${ }^{9}$ :

$$
\beta \int_{\delta}^{\delta^{b}}\left[\int_{\alpha_{L}}^{\alpha^{*}}\left(r+c-\alpha_{1}\right) f\left(\alpha_{2}\right) d a_{2}+\beta \int_{\alpha^{*}}^{\alpha_{H}}\left(1+\alpha_{2}\right)\left(r+c-\alpha_{1}\right) f\left(\alpha_{2}\right) d \alpha_{2}\right] g(\delta) d \delta
$$

$$
+\beta \int_{\left(\underline{S}_{Q} \delta_{g}\right.}^{\delta}\left[\int_{\alpha_{L}}^{\alpha^{*}}\left(r+c-\alpha_{1}\right) f\left(\alpha_{2}\right) d a_{2}+\int_{\alpha^{*}}^{\alpha_{H}}\left(\left(r+1-\alpha_{1}\right)-\beta\left(1+\alpha_{2}\right)\right) f\left(\alpha_{2}\right) d \alpha_{2}\right] g(\delta) d \delta
$$

$$
+\beta \int_{\delta}\left[\int_{\alpha_{L}}^{\left(1+\underline{S}_{0}\right)}\left(g /(1+g)+r-\alpha_{1}\right) f\left(\alpha_{2}\right) d a_{2}+\int_{\alpha^{*}}^{\alpha^{*}}\left(\int_{\alpha^{\prime}}^{\alpha_{H}} \beta\left(\alpha_{2}-\alpha_{2}^{\prime}\right) f\left(\alpha_{2}^{\prime}\right) \mathrm{d} \alpha^{\prime}+\left(r-\alpha_{1}\right)\right) f\left(\alpha_{2}\right) \mathrm{d} \alpha_{2}\right] g(\delta) \mathrm{d} \delta
$$

The signs of the terms in this expression depend on the following considerations: The first line in (10) corresponds to Region 1 in Figure 1 , in which there is forced liquidation. If the liquidation cost $c$ is zero, this is unambigously negative since $\alpha_{1}>r$. This reflects the fact that where liquidation is costless, securities are dominated by loans. As c increases, so does the value of holding securities against forced liquidation. In the second line, Region 2, c also directly affects the comparison between loans and securities when loans will be liquidated. Otherwise, the return from securities is compared to the return over the 
life of the loans. The third line in (10) corresponds to Region 3, where deposit inflows are sufficient to buy new loans. The first integral shows that if old loans are poor so that bankcruptcy is anticipated, the marginal benefit of securities over loans is $g /(1+g)+r-\alpha_{1}$. The $g /(1+g)$ reflects that the deposits backing the securities can profitably be returned to reduce the equity requirement, allowing a larger current dividend to be paid. The final integral compares the expected return on loans made at time 0 and at time 1.

With symmetric information and therefore no liquidation costs, the first order condition corresponding to (10) would be unambiguously negative, so that no securities would be held. The next section demonstrates that with asymmetric information, securities can be a significant component of a bank's optimal portfolio, assuming reasonable parameter values. The proportion of securities held is quite sensitive to changes in the distributions of loan quality and withdrawals.

\section{Simulation Results}

In this section we explore the implications of the model via simulations. Tables 1 and 2 illustrate the effect on portfolio composition, bank value, and ex ante probability of failure, of changing the distribution of withdrawals and loan quality. Table 3 shows the effect of varying the lemons discount exogenously. The main qualitative results can be summarized as follows:

- A mean preserving increase in the variance of withdrawals lowers the value of the bank, and leads to an increase in security holdings. 
The effect on the probability of failure is ambiguous.

- A mean preserving increase in the variance of loan quality has an ambiguous effect on the value of the bank, and an ambiguous effect on security holdings. The probability of failure increases.

- Exogenously increasing the lemons discount decreases the value of the bank, increases security holdings, and has an ambiguous effect on the probability of failure.

Unlike many models of the banking firm, this model distinguishes between balance-sheet risk and bankruptcy risk. It is clear from the results that looking at the effect of a policy change on portfolio composition will generally not be informative about the effect of the policy on the probability of failure. In simulations of this model, the most important determinants of the probability of failure are the distribution of loan quality and the equity requirement; other factors were always second order. Intuitively, a bank can largely offset changes in factors such as an increase in the variance of withdrawals through its choice of security holdings. As a result, a change in the variance of withdrawals may have little effect on the equilibrium probability of failure. However, there is nothing the bank can do to reduce the ex ante probability of receiving bad loans as long as it invests in loans at all. Thus, a bank with a high ratio of securities to loans may nevertheless have a high probabilty of bankruptcy if the variance of loan quality is high. 
Table 1: The Effect on Bank Value, Porfolio Choice, and Bankruptcy

Probability of Changing the Variance of Withdrawals

$$
\text { Fixed Parameters: } \begin{aligned}
& r=.03, \alpha_{1}=.06, g=.05, \alpha_{L}=-.07, \alpha_{H}=.13, D=10 . \\
& c=1-\left(1+\alpha_{L}\right) /(1+r)
\end{aligned}
$$

$\begin{array}{cccl}\text { Withdrawal Distribution } & \text { Value of Bank } & \text { of Portfolio } & \text { Probability } \\ \left(\text { uniform on }\left[\delta_{L}, \delta_{H}\right]\right) & \text { per } \$ 1 & \text { in Securities } & \text { of Failure }\end{array}$

$\begin{array}{lllrl}\delta_{\mathrm{L}}=-.5 & \delta_{\mathrm{H}}=.5 & .3665 & 0.0 & 25.21 \\ \delta_{\mathrm{L}}=-1 & \delta_{\mathrm{H}}=1 & .3554 & .5 & 25.16 \\ \delta_{\mathrm{L}}=-2 & \delta_{\mathrm{H}}=2 & .3311 & 4.3 & 25.18 \\ \delta_{\mathrm{L}}=-3 & \delta_{\mathrm{H}}=3 & .3069 & 7.7 & 25.18 \\ \delta_{\mathrm{L}}=-4 & \delta_{\mathrm{H}}=4 & .2826 & 10.8 & 25.17\end{array}$

As one would expect, increasing the variance of withdrawals always reduces the value of the bank ${ }^{10}$, because it increases that probability that the bank will have to sell loans at a discount. To protect loans from liquidation, the bank increases security holdings as deposits become more uncertain. In Table 1 , the support of the distribution of withdrawals is varied from $+/-58$ to $+/-408$ of deposit liabilities, holding other parameters constant. The discount $c$ is set to the level that would prevail if there were no forced sales. For this specification, the model explains only a fraction of actual bank security holdings. However, with the addition of loan commitments in section 6 , the model predicts much larger security holdings. 
Table 2a: The Effect of Changing the Variance of Loan Quality (with $c$ endogenous)

Fixed Parameters: $r=.03, \alpha_{1}=.06, g=.05, \delta_{L}=-3 ., \delta_{H}=3 ., D=10$.

$$
c=1-\left(1+\alpha_{L}\right) /(1+r)
$$

Payoff Distribution Value of Bank ( uniform on $\left[\alpha_{L}, \alpha_{H}\right]$ ) per $\$ 1$
$\alpha_{L}=-.04 \quad \alpha_{H}=.10$
.2774
$\alpha_{L}=-.06 \quad \alpha_{H}=.12$
.2948
$\alpha_{\mathrm{L}}=-.08 \quad \alpha_{\mathrm{H}}=.14$
.3205
$\alpha_{\mathrm{L}}=-.10 \quad \alpha_{\mathrm{H}}=.16$
.3504

$\begin{array}{rr}0.6 & 14.73 \\ 5.8 & 22.46 \\ 8.6 & 27.40 \\ 10.6 & 30.84\end{array}$

$z$ of Portfolio

in Securities

Probability

of Failure

Table 2b: The Effect of Changing the Variance of Loan Quality (with c exogenous)

Fixed Parameters: $c=.1, r=.03, \alpha_{1}=.06, g=.05, \delta_{L}=-3, \delta_{H}=3, D=10$.

Payoff Distribution Value of Bank ( uniform on $\left[\alpha_{L}, \alpha_{H}\right]$ ) per $\$ 1$

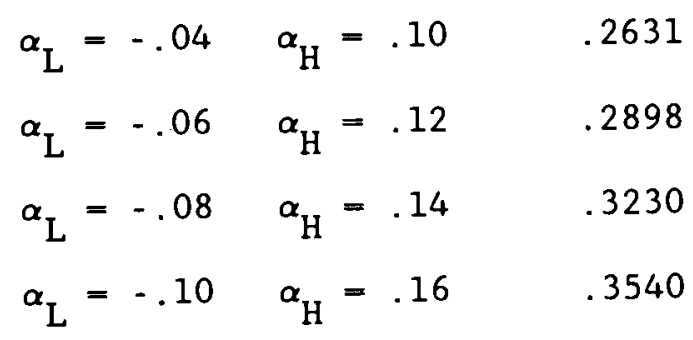

8 of Portfolio in Securities

9.4

8.5

7.3

6.1
Probability

of Failure 
In both Tables $2 \mathrm{a}$ and $2 \mathrm{~b}$ we vary the distribution of loan payoffs, but perform quite different experiments. In Table $2 a$, as loan variance increases, the lemons discount is varied simultaneously to reflect that loans sold in the secondary market receive the price for the lowest quality loans. This represents an increase in the riskiness of the operating environment. Security holdings rise as the variance of the return on loans rises, because for these parameters the expected cost of liquidation rises more rapidly than the gain from more valuable insurance.

Table $2 b$ answers the question of how, in a stable environment, an individual bank's value and security holdings are affected by changing the distribution of loan quality. Since the lemons discount remains constant, increased variance increases the value of FDIC insurance. The bank substitutes away from securities as variance increases, and bank value increases. This increase in bank value is a standard result in the literature on FDIC insurance (e.g., Merton[1977]).

Although these simulations indicate that the value of the bank increases with variance in both Tables $2 a$ and $2 b$, other parameters can yield a decreasing bank value in Table 2a. An increase in the variability of loan quality will raise the lemons cost and hence the cost of liquidating loans, and also raise the value of insurance. If deposit variability is high, the increase in expected costs from loan liquidations will offset the increased insurance benefit, and bank value can then fall. Note that in both tables the probability of failure is primarily a function of the variance of loan quality.

Finally, Table 3 illustrates how an exogenous change in the lemons cost 
will impact the bank. For fixed distributions of loan quality and withdrawals, an increase in $c$ has the expected effects: the value of the bank falls, and precautionary holdings of securities rise. In all parameterizations tested, the probability of failure fell with the increase in the lemons cost, presumably because the safety gained from increased security holdings more than offset the increased bankruptcy risk due to the higher liquidation cost.

Table 3: The Effect of Changing the Lemons Cost Exogenously

Fixed Parameters: $\quad r=.03, \alpha_{1}=.06, g=.05, \delta_{L}=-3 . \delta_{H}=3 . D=10$.

$$
\alpha_{L}=-.08, \alpha_{H}=.14
$$

\begin{tabular}{cccc}
\hline Lemons Cost & $\begin{array}{c}\text { Value of Bank } \\
\text { per \$1 }\end{array}$ & $\begin{array}{l}\text { \& of Portfolio } \\
\text { in Securities }\end{array}$ & $\begin{array}{c}\text { Probability } \\
\text { of Failure }\end{array}$ \\
.05 & .3535 & 0.0 & 27.70 \\
.07 & .3396 & 0.0 & 27.55 \\
.10 & .3230 & 7.3 & 27.42 \\
.30 & .3025 & 17.7 & 27.26 \\
.30 & .2954 & 21.3 & 27.20 \\
\hline
\end{tabular}

The sensitivity of the model predictions to $\alpha_{1}$, the return on loans at time 1, was also tested. As expected, a higher $\alpha_{1}$ leads to a higher. percentage of loans in the portfolio, ceterus paribus, because it increases the expected payoff from loans relative to securities. Changing $\alpha_{1}$ has little effect on the probability of failure. In all the results reported, $\alpha_{1}$ was set to a $3 \%$ premium over the riskfree rate. 
With this basic understanding of the effect of exogenous environmental changes on bank portfolio choice, riskiness and value, we turn to the question of how banks will be affected by various policies and institutions.

\section{Loan Commitments as a Source of Uncertainty about Cash Requirements}

Up to this point, we have focussed on stochastic deposit flows as the source of uncertainty about liquidity requirements. While uncertainty about deposit flows is significant at times, one could argue that often deposits are fairly stable. Deposit uncertainty alone may not generate a sufficient demand for securities to explain the actual magnitude of securities held by banks. There are, however, common bank practices that can generate a substantial need for liquidity and hence induce a substantial demand for securities: off-balance sheet activities such as loan commitments and backup lines of credit.

Any bank obligation which could result in an immediate demand for funds is equivalent in our model to a stochastic deposit outflow. Drawdowns of loan commitments, for example, are like deposit outflows in the sense that

outsiders make claims to bank resources. ${ }^{11}$ suppose that a bank has outstanding loan commitments of $M$, and that the probability of takedowns is distributed on $[0, M]$. The net effect of zero-mean deposit uncertainty and loan commitments is a negative mean cash outflow. In fact, loan commitments and backup lines of credit are a surprisingly large fraction of bank assets. In 1985 the ratio of off-balance-sheet commitments to assets was 2098 for the largest seven banks (Andrews and Sender, 1986). For these banks, standby letters of credit and loan commitments average over fifty percent of 
assets.

Table 4 shows how security holdings are affected by changes in the distribution of required cash outflows. The mean outflow is negative to reflect takedowns of off-balance-sheet commitments.

Table 4: The Effect on Bank Value and Porfolio Choice of Deposit and Loan Commitment Variance

Fixed Parameters: $\quad r=.03, \alpha_{1}=.06, g=.05, \alpha_{L}=-.07, \alpha_{H}=.13, D=10$.

$$
c=1-\left(1+\alpha_{L}\right) /(1+r)
$$

$\begin{array}{ccccc}\begin{array}{c}\text { Withdrawal Distribution } \\ \left(\text { uniform on }\left[\delta_{\mathrm{L}}, \delta_{\mathrm{H}}\right]\right)\end{array} & \begin{array}{c}\text { Value of Bank } \\ \text { per } \$ 1\end{array} & \begin{array}{l}\text { o of Portfolio } \\ \text { in Securities }\end{array} & \begin{array}{c}\text { Probability } \\ \text { of Failure }\end{array} \\ \delta_{\mathrm{L}}=-2 & \delta_{\mathrm{H}}=3 & .3009 & 10.5 & 25.15 \\ \delta_{\mathrm{L}}=-2 & \delta_{\mathrm{H}}=4 & .2706 & 17.2 & 25.11 \\ \delta_{\mathrm{L}}=-2 & \delta_{\mathrm{H}}=5 & .2404 & 23.8 & 25.06 \\ \delta_{\mathrm{L}}=-1 & \delta_{\mathrm{H}}=4 & .2645 & & \\ \delta_{\mathrm{L}}=-1 & \delta_{\mathrm{H}}=5 & .2343 & 20.4 & 25.08 \\ \delta_{\mathrm{L}}=-1 & \delta_{\mathrm{H}}=6 & .2041 & 27.0 & 25.02\end{array}$

Comparing these results with the zero-mean simulations in Table 1, we find that precautionary holdings of securities are substantially increased. As expected, bank value falls with an increase in free loan commitments because the bank substitutes towards securities to meet the larger expected cash outflows. The change in bank value from increasing the size of expected loan commitments is a measure of the cost of these additional 
commitments to the bank. ${ }^{12}, 13$ since banks increase securities to meet increases in expected loan commitment takedowns, the effect of loan commitments on the probability of failure is small in this model.

From a regulatory perspective, the fact that off-balance-sheet commitments have a small (possibly negative) effect on the probability of failure implies that there is no need to regulate loan comitments to protect against increases in risk associated with bank liquidity. This analysis is incomplete, however, since it ignores the possibility that the risk of off-balance-sheet items will systematically differ from those onbalance-sheet .

\section{Will Increasing the Equity Requirement Make Banks Safer?}

The recent increase in the rate of bank failures has sparked debate about whether bank capital requirements should be raised. This model provides a framework in which to examine the expected consequences of changes in equity requirements on bank portfolio choice, profitability, and bankruptcy risk. For both portfolio choice and bankruptcy risk, we find a marked difference between the short and long-run effects of an increase in equity requirements. In the long-run, an increase in the equity requirement reduces bankruptcy risk in all simulation scenarios tested, and tends to result in slightly higher security holdings. In the short-run, banks hold proportionally fewer securities, and the probability of failure can either rise or fall. Higher equity requirements always lower the value of the bank to stockholders.

For the short-run analysis, the policy change is assumed to occur after 
the initial purchase of securities and loans, and after loan quality is known, but before a signal is received about liquidity needs. To respond to an increase in $g$ the bank in the short-run can either sell assets and refund deposits, or issue new equity. Since by assumption no equity is issued, consider the case in which assets are sold and deposits refunded. Securities can be sold without a lemons cost, while loans are costly to sell. In period 0 , the bank is indifferent at the margin about changing a dollar of loans for securities. Once the bank learns about loan quality, however, selling loans has a cost for all but the worst banks. Initially the bank will prefer to sell securities if it must reduce assets. Thus the assets remaining on the balance sheet will be riskier, at least until such time that new deposits allow the bank to adjust to the new long run equilibrium.

The amount of deposits that must be returned when the equity requirement shifts from $g$ to $g^{\prime}$ is found by solving for $\delta_{v}$ in the equity constraint using eq. (1):

$$
\begin{aligned}
& L_{0}+S_{0}-\delta_{v}=\left(D-\delta_{v}\right)\left(1+g^{\prime}\right) \quad \Rightarrow \\
& \delta_{v}=D\left(g^{\prime}-g\right) / g^{\prime}
\end{aligned}
$$

The value of securities sold will equal the amount of deposits returned, if the bank has sufficient securities. For example, if equity requirements are raised from 58 to 5.58 , then 9.18 of deposits would have to be returned. If equity requirements were to rise from 58 to $78,28.68$ of deposits would have to be returned. 
The effect of increasing the equity requirement on the probability of failure depends on the size of the increase. If the increase is small so that all deposit returns can be funded by selling securities, simulation results suggest that banks will be safer due to the larger equity cushion. However, for an increase in equity requirements that forces loans to be sold at a discount, the effect on bankruptcy probability is ambiguous. Selling loans at a discount increases the probability of failure, while increasing equity reduces the probability.

The long-run experiment involves changing capital requirements prior to selection of securities and loans in period 0 . The simulations in Table 5 illustrate typical long-run results. Most striking is the effect on the probability of bankruptcy. The increased equity requirement reduces bankruptcy risk by providing a bigger buffer against bad loans. The cost of this buffer is a lower expected return to equity holders.

The change in equity requirements also effects the equilibrium amount of security holdings. It appears that an increase in the equity requirement slightly raises the long-run holding of securities for a large range of parameters. The net effect of an increase in $g$ on security holdings is a priori ambiguous, however ${ }^{14}$. The higher the percentage of loans in the bank portfolio, the more insurance is worth. At the same time, the higher the percentage of securities, the less is the expected cost of liquidating loans. An increase in $g$ reduces the value of deposit insurance, which reduces the marginal benefit of investing in loans. On the other hand, an increase in $g$ also reduces the magnitude of deposit flows relative to the size of the portfolio as a whole, which reduces the marginal benefit of investing in securities. The simulation results in Table 5 show that for 
the range of $g$ considered, the first effect dominates: as insurance becomes worth less per dollar of equity, the bank holds more securities to reduce expected costs of liquidating loans.

Table 5: The Effect on Long-run Bank Value and Porfolio Choice of Changing the Equity Requirement

\begin{tabular}{cccc} 
Fixed Parameters: $\mathrm{r}=.03, \alpha_{1}=.06, \delta_{\mathrm{L}}=-2, \delta_{\mathrm{H}}=4, \mathrm{D}=10$. & \\
$\mathrm{c}=1-\left(1+\alpha_{\mathrm{L}}\right) /(1+\mathrm{r}), \alpha_{\mathrm{L}}=-.06, \alpha_{\mathrm{H}}=.12$ & \\
\hline Equity Requirement & $\begin{array}{c}\text { Value of Bank } \\
\text { per } \$ 1\end{array}$ & $\begin{array}{l}\text { o of Portfolio } \\
\text { in Securities }\end{array}$ & $\begin{array}{l}\text { Probability } \\
\text { of Failure }\end{array}$ \\
$\mathrm{g}=.03$ & .2947 & 14.3 & 32.90 \\
$\mathrm{~g}=.05$ & .2603 & 15.5 & 22.40 \\
$\mathrm{~g}=.06$ & .2489 & 15.9 & 17.31 \\
$\mathrm{~g}=.07$ & .2413 & 16.2 & 12.34 \\
$\mathrm{~g}=.09$ & .2368 & 16.2 & 2.70
\end{tabular}

\section{Conclusion}

This paper presents a model of bank portfolio choice in which loan sales are costly due to asymmetric information about loan quality. Riskneutral banks will hold riskless, marketable securities even though FDIC insurance provides an incentive to maximize asset risk.

The model provides a powerful framework in which to predict the response of the banking sector to changes in the operating environment, and 
to policy changes. Perhaps the most valuable contribution of the model is that it highlights the distinction between balance-sheet risk and the overall risk of failure. Our results suggest that simple balance-sheet measures such as the ratio of securities to loans are a poor indicator of a bank's soundness. The most important factors affecting bankruptcy risk are 1) the variance of loan quality in the economy, and 2) the amount of equity. Increases in required bank equity are shown to have the long-run effect of making banks safer, with ambiguous short-run effects. Because of the extra equity buffer arising from an increase in required equity, it is possible for banks to become safer in the short run even though the ratio of loans to securities will unambiguously rise.

We also show that with loan commitments, banks with very different ratios of loans to securities can have similar bankruptcy probabilities. Banks with greater off-balance-sheet commitments, such as loan commitments, will hold additional securities in order to offset the liquidation risk posed by the commitments. For the simulation results we present, bankruptcy risk is surprisingly insensitive to the existence of loan commitments. 
APPENDIX A

The portfolio problem starting in period 1 , given $S_{0}$ and $L_{0}$, is considered here. The bank chooses $\Delta \mathrm{S}_{0}, \Delta \mathrm{L}_{0}, \mathrm{~L}_{1}, \mathrm{~S}_{1}$, and $\delta_{\mathrm{v}}$ to maximize

$$
r \mathrm{~S}_{0}+\Delta \mathrm{S}_{0}+\alpha_{1} \mathrm{~L}_{0}+\Delta \mathrm{L}_{0}(\mathrm{l}-\mathrm{c})-\mathrm{rD}-\delta-\delta \mathrm{v}-\mathrm{L}_{1}-\mathrm{S}_{1}+
$$

$$
\beta \int_{\hat{\alpha}}^{\alpha_{H}}\left[\left(\mathrm{~L}_{0}-\Delta \mathrm{L}_{0}\right)\left(1+\alpha_{2}\right)+\mathrm{L}_{1}\left(1+\alpha_{2}^{\prime}\right)+\left(\mathrm{S}_{0}-\Delta_{0}\right)(1+\mathrm{r})-(1+r)\left(D-\delta-\delta_{\mathrm{v}}\right)\right] f\left(\alpha_{2}^{\prime}\right) \mathrm{d} \alpha_{2}^{\prime}
$$

subject to the following constraints. (Multipliers are in parentheses.)

(A2) $\quad \mathrm{rS}_{0}+\Delta \mathrm{S}_{0}+\alpha_{1} \mathrm{~L}_{0}+\Delta \mathrm{L}_{0}(1-\mathrm{c})-\mathrm{rD}-\delta-\delta_{\mathrm{v}}-\mathrm{L}_{1}-\mathrm{S}_{1} \geq 0 \quad\left(\lambda_{1}\right)$

(AB) $\mathrm{L}_{0}-\Delta \mathrm{L}_{0}+\mathrm{L}_{1}+\mathrm{S}_{0}-\Delta \mathrm{S}_{0}+\mathrm{S}_{1}-\left(D-\delta-\delta_{\mathrm{v}}\right)(1+\mathrm{g}) \geq 0 \quad\left(\lambda_{2}\right)$

(Af) $\quad \Delta S_{0} \geq 0 \quad\left(\lambda_{3}\right)$

(AS) $\quad s_{0}-\Delta S_{0} \geq 0 \quad\left(\lambda_{4}\right)$

(Ab) $\quad \Delta \mathrm{L}_{0} \geq 0 \quad\left(\lambda_{5}\right)$

(AT) $\quad \mathrm{L}_{0}-\Delta \mathrm{L}_{0} \geq 0 \quad\left(\lambda_{6}\right)$

(AB) $\quad \mathrm{s}_{1} \geq 0 \quad\left(\lambda_{7}\right)$

(Aq) $\mathrm{L}_{1} \geq 0 \quad\left(\lambda_{8}\right)$

(A10) $\delta_{\mathrm{v}} \geq 0 \quad\left(\lambda_{9}\right)$

(AlI) D $-\delta-\delta_{\mathrm{v}} \geq 0 \quad\left(\lambda_{10}\right)$

The first order conditions for a maximum are given by: ${ }^{15}$

(A12) $\Delta \mathrm{S}_{0}: \quad 1-\beta \int(1+r) f\left(\alpha_{2}^{\prime}\right) \mathrm{d} \alpha_{2}^{\prime}+\lambda_{1}-\lambda_{2}+\lambda_{3}-\lambda_{4}=0$ 
(A13) $\mathrm{S}_{1}:-1+\beta \int(1+\mathrm{r}) \mathrm{f}\left(\alpha_{2}^{\prime}\right) \mathrm{d} \alpha_{2}^{\prime}-\lambda_{1}+\lambda_{2}+\lambda_{7}=0$

(A14) $\mathrm{L}_{1}:-1+\beta \int\left(1+\alpha_{2}^{\prime}\right) \mathrm{f}\left(\alpha_{2}^{\prime}\right) \mathrm{d} \alpha_{2}^{\prime}-\lambda_{1}+\lambda_{2}+\lambda_{8}=0$

(A15) $\Delta \mathrm{L}_{0}: \quad 1-\mathrm{c}-\beta \int\left(1+\alpha_{2}\right) f\left(\alpha_{2}^{\prime}\right) \mathrm{d} \alpha_{2}^{\prime}+\lambda_{1}(1-\mathrm{c})-\lambda_{2}+\lambda_{5}-\lambda_{6}=0$

(A16) $\delta_{\mathrm{v}}:-1+\beta \int(1+\mathrm{r}) \mathrm{f}\left(\alpha_{2}^{\prime}\right) \mathrm{d} \alpha_{2}^{\prime}-\lambda_{1}+\lambda_{2}(1+\mathrm{g})+\lambda_{9}-\lambda_{10}=0$

Since the constraints are inequality constraints, the Kuhn-Tucker theorem applies, and for each constraint either the multiplier will be zero or the constraint will be slack.

Proof of Lemmas 1 and 2: Subtracting (A13) from (A14) yields

$$
\beta \int_{\hat{\alpha}}(1+\mathrm{r}) f\left(\alpha_{2}^{\prime}\right) \mathrm{d} \alpha_{2}^{\prime}+\lambda_{7}=\beta \int_{\hat{\alpha}}\left(1+\alpha_{2}^{\prime}\right) f\left(\alpha_{2}^{\prime}\right) \mathrm{d} \alpha_{2}^{\prime}+\lambda_{8}
$$

Since

$$
\beta \int_{\alpha_{L}}(1+r) f\left(\alpha_{2}^{\prime}\right) \mathrm{d} \alpha_{2}^{\prime}=\beta \int_{\alpha_{L}}\left(1+\alpha_{2}^{\prime}\right) f\left(\alpha_{2}^{\prime}\right) \mathrm{d} \alpha_{2}^{\prime}
$$

it follows that

$$
\beta \int_{\hat{\alpha}}(1+r) f\left(\alpha_{2}^{\prime}\right) \mathrm{d} \alpha_{2}^{\prime} \leq \beta \int \frac{\hat{\alpha}}{\left(1+\alpha_{2}^{\prime}\right) f\left(\alpha_{2}^{\prime}\right) \mathrm{d} \alpha_{2}^{\prime}}
$$

with equality only when $\hat{\alpha}=\alpha_{L}$, which implies $\lambda_{7} \geq \lambda_{8}$. If $L_{1}=0$, then $\lambda_{8}>$ 0 which implies $\lambda_{7}>0$ and therefore $S_{1}=0$. If $L_{1}$ is positive and $\hat{\alpha}>\alpha_{L}$, then $\lambda_{8}=0$, and $\lambda_{7}>0$, so SI $=0$. If LI is positive and $\hat{\alpha}=\alpha_{L}$, then the bank is indifferent between $S_{1}$ and $L_{1}$, so without loss of generality $s_{1}$ can be set to zero. Therefore $S_{1}$ is always 0 .

Note that for $\Delta S_{0}=S_{0}$, eq. $(A 12)=$ - eq. (A13). Selling old securities is equivalent to not buying new securities. If assets other than 
old loans are to be held they will be new loans.//

Proof of Lemmas 3 and $4:^{16}$ We proceed by deriving the value function for this region and computing the optimal $\Delta_{0}$ and $\delta_{\mathrm{v}}$. For $\delta \geq \mathrm{S}_{0} /(1+\mathrm{g})$, no new loans can be purchased without either selling old loans or foregoing dividends. We assume that the discount $c$ is sufficiently large so that old, poor loans cannot be profitably sold in order to buy new loans (if $c$ is large enough, liquidating old loans will bankrupt the bank). Foregoing a dividend to buy a new loan can easily be shown to have an expected return less than or equal to the riskfree rate, so no new loans are purchased. Using the fact that no new loans are purchased and Lemmas 1 and 2 , the decision reduces to:

(A17) $\max _{\Delta \mathrm{L}_{0}, \delta_{\mathrm{v}}}\left\{\mathrm{S}_{0}(1+\mathrm{r})+\alpha_{1} \mathrm{~L}_{0}+\Delta \mathrm{L}_{0}(1-\mathrm{c})-\mathrm{rD}-\delta-\delta_{\mathrm{v}}+\right.$

$$
\left.\beta \max \left[0,\left(\mathrm{~L}_{0}-\Delta \mathrm{L}_{0}\right)\left(1+\alpha_{2}\right)-(1+\mathrm{r})\left(\mathrm{D}-\delta-\delta_{\mathrm{v}}\right)\right]\right\}
$$

subject to

$$
\begin{aligned}
& \Delta \mathrm{L}_{0} \leq \mathrm{L}_{0}-\left(\mathrm{D}-\delta-\delta_{\mathrm{v}}\right)(1+\mathrm{g}) \equiv \mathrm{L}^{*} \\
& \Delta \mathrm{L}_{0} \geq \max \left[0, \frac{\delta+\delta_{\mathrm{v}}-\mathrm{S}_{0}(1+\mathrm{r})-\mathrm{L}_{0} \alpha_{1}+\mathrm{rD}}{(1-\mathrm{c})}\right] \equiv \mathrm{L}_{*}
\end{aligned}
$$

where (A18) is the equity constraint, and (A19) gives the minimum liquidation necessary to return the required deposits. Partially differentiating (Al7) with respect to $\mathrm{L}_{0}$ gives

$(A 20)(1-c)-\beta\left(1+\alpha_{2}\right) I_{>0}$

where $I_{>0}=0$ if the bank is bankrupt, and $=1$ if the bank is solvent in 
period 2. Since $(1-c)=\beta\left(1+\alpha_{L}\right)$, the sign of (A20) depends on whether or not there is bankruptcy in period 2. The value function will be maximized at either $\mathrm{L}_{*}$ or $\mathrm{L}^{*}$, i.e. there is a corner solution for liquidations.

Using the fact that $\Delta \mathrm{L}_{0}$ equals either $L_{*}$ or $L^{*}$, we consider the two cases to determine $\delta_{\mathrm{v}}$ :

Case 1: $\Delta \mathrm{L}_{0}=\mathrm{L}_{*}$. Substituting (A19) into (A17), it follows that (A17) decreases in $\delta_{\mathrm{v}}$, so $\delta_{\mathrm{v}}=0$.

Case 2: $\Delta \mathrm{L}_{0}=\mathrm{L}^{*}$. Substituting (A18) into (A17), the fact that $(1-\mathrm{c})(1+\mathrm{g})<$ 1 establishes that (A17) decreases in $\delta_{\mathrm{v}}$, so $\delta_{\mathrm{v}}=0$.

Using the fact that $\delta_{v}=0$, we can choose between $L_{*}$ and $L^{*}$. This can be done evaluating (A17) at each of these points, which reduces to choosing

$\max \left(L_{*}(1-c)+\beta \max \left[0,\left(L_{0}-L_{*}\right)\left(1+\alpha_{2}\right)-(1+r)(D-\delta)\right]\right.$,

$$
L^{*}(1-C)+\beta \max \left[0,\left(L_{0}-L^{*}\right)\left(1+\alpha_{2}\right)-(1+r)(D-\delta)\right] \text { ) }
$$

Clearly the choice depends on $\alpha_{2}$. With quite a bit of algebra, the critical level of $\alpha_{2}$ can be shown to be that given in (9).

Proof of Lemma 5: As in Lemma 3 and 4, it can be shown that foregoing a dividend to invest in new loans is unprofitable. This along with Lemmas 1 and 2 can be used to simplify the value function:

(A21) $\underset{\Delta \mathrm{L}_{0}, \mathrm{~L}_{1}, \delta_{\mathrm{v}}}{\max } \mathrm{S}_{0}(1+\mathrm{r})+\alpha_{1} \mathrm{~L}_{0}+\Delta \mathrm{L}_{0}(1-\mathrm{c})-\mathrm{rD}-\delta-\delta_{\mathrm{v}}+$
$\beta \int_{\hat{\alpha}}^{\alpha_{\mathrm{H}}}\left[\left(\mathrm{L}_{0}-\Delta \mathrm{L}_{0}\right)\left(1+\alpha_{2}\right)+\mathrm{L}_{1}\left(1+\alpha_{2}^{\prime}\right)-(1+\mathrm{r})\left(\mathrm{D}-\delta-\delta_{\mathrm{v}}\right)\right] f\left(\alpha_{2}^{\prime}\right) \mathrm{d} \alpha_{2}^{\prime}$ 
subject to (A18) and (A19). The bank has $\mathrm{S}_{0} /(1+\mathrm{g})-\delta$ in free deposits which it will either use to invest in new loans or to repay depositors (taking it home as a dividend would violate the equity constraint). As in Lemma 3 and 4 , the fact that $1-(1-c)(1+g)>0$ implies that old loans will not be sold in order to return deposits, and it is assumed that $c$ is sufficiently large so that old loans won't be sold to buy new loans. It remains to choose whether to buy new loans or to return deposits. To satisfy the equity constraint, it must be the case that

$$
\mathrm{L}_{1}=\left(\mathrm{S}_{0} /(1+\mathrm{g})-\delta-\delta_{\mathrm{v}}\right)(1+\mathrm{g})
$$

Substituting (A22) into (A21) and differentiating with respect to $\delta_{\mathrm{V}}$ reduces to:

(A23) $g+\beta \int_{\hat{\alpha}}^{\alpha}\left[(1+r)-\left(1+\alpha_{2}^{\prime}\right)(1+g)\right] f\left(\alpha_{2}^{\prime}\right) d \alpha_{2}^{\prime}$

Algebra establishes that choosing $\delta_{\mathrm{v}}$ so that (A23) equals zero is a local minimum. Thus either only loans are purchased, or only deposits are returned. As in Lemmas 3 and 4 , it can be shown that the choice depends monotonically on the realization of $\alpha_{2}$, and that the critical level is given by (9).

\section{APPENDIX B}

The value function at time 0 is

$$
-g D+
$$


35

$$
\begin{aligned}
& \beta \int_{\delta}^{\delta^{b}} \int_{\alpha_{L}}^{\alpha^{*}}\left[\mathrm{~s}_{0}(1+\mathrm{r})+\alpha_{1} \mathrm{~L}_{0}-\delta \cdot r D+(1-\mathrm{c}) \mathrm{L}_{0}-(D-\delta)(1+g)(1-\mathrm{c})\right] f\left(\alpha_{2}\right) g(\delta) \mathrm{d} \alpha_{2} \mathrm{~d} \delta \\
& +\beta^{2} \int_{\delta^{1}}^{\delta^{\mathrm{b}}} \int_{\alpha^{*}}^{\alpha^{\mathrm{H}}}\left[\mathrm{L}_{0}\left(1+\alpha_{2}\right)-\left(\delta-\mathrm{S}_{0}(1+\mathrm{r})-\mathrm{L}_{0} \alpha_{1}+\mathrm{rD}\right) \frac{\left(1+\alpha_{2}\right.}{(1-\mathrm{c})^{2}}-(1+r)(D-\delta)\right] f\left(\alpha_{2}\right) \mathrm{g}(\delta) \mathrm{d} \alpha_{2} \mathrm{~d} \delta \\
& +\beta \int_{(1+g)}^{\delta^{1}} \int_{\alpha_{L}}^{\alpha^{*}}\left[\mathrm{~S}_{0}(1+r)+\alpha_{1} L_{0}-\delta-r D+(1-c) L_{0}-(D-\delta)(1+g)(1-c)\right] f\left(\alpha_{2}\right) g(\delta) d \alpha_{2} d \delta \\
& +\beta \int_{(1+g)}^{\delta^{1}} \int_{\alpha^{*}}^{\alpha}\left[\mathrm{S}_{0}(1+\mathrm{r})+\mathrm{L}_{0} \alpha_{1}-\mathrm{D}(1+\mathrm{r})+\beta \mathrm{L}_{0}\left(1+\alpha_{2}\right)\right] f\left(\alpha_{2}\right) \mathrm{g}(\delta) \mathrm{d} \alpha_{2} \mathrm{~d} \delta \\
& +\beta \int_{\delta}^{(1+g)} \int_{\alpha_{L}}^{\alpha^{*}}\left[S_{0}(1+r)+L_{0} \alpha_{1}-r D-s_{0} /(1+g)\right] f\left(\alpha_{2}\right) g(\delta) d \alpha_{2} d \delta \\
& +\beta \int_{\delta}^{\underline{(1+g)}} \int_{\alpha^{\star}}^{\mathrm{H}}\left[\mathrm{S}_{0}(1+\mathrm{r})+\mathrm{L}_{0} \alpha_{1}-\mathrm{rD}-\delta-\left(\mathrm{S}_{0}-\delta(1+g)\right)\right] f\left(\alpha_{2}\right) g(\delta) \mathrm{d} \alpha_{2} \mathrm{~d} \delta \\
& +\beta^{2} \int_{\delta_{L}}^{\underline{(1+g)}} \int_{\alpha^{*}}^{\alpha_{H}} \int_{\hat{\alpha}}^{\alpha_{H}^{H}}\left[L_{0}\left(1+\alpha_{2}\right)+\left(S_{0}-\delta(1+g)\right)\left(1+\alpha 2^{\prime}\right)-(1+r)(D-\delta)\right] f\left(\alpha_{2}^{\prime}\right) f\left(\alpha_{2}\right) g(\delta) d \alpha_{2}^{\prime} \mathrm{d} \alpha_{2} \mathrm{~d} \delta
\end{aligned}
$$




\section{REFERENCES}

Akerlof, George. "The Market for Lemons: Qualitative Uncertainty and he Market Mechanism", Quarterly Journal of Economics 84 (1970), 488-500.

Andrews, Suzanna and Henry Sender. "Off Balance Sheet Risk: Where is it Leading the Banks?" Institutional Investor, January 1986, pp. 75-84.

Baltensperger, Ernst. "The Precautionary Demand for Reserves", American Economic Review 64 (March, 1974), 205-10.

Frost, Peter A. "Banks' Demand for Excess Reserves", Journal of Political Economy, 1971 (July/August), 805-25.

Hart, Oliver D. and Dwight M. Jaffee. "On the Application of Portfolio Theory to Depository Financial Intermediaries", Review of Economic Studies 41, (January, 1974), 129-47.

Hawkins, Gregory. "An Analysis of Revolving Credit Agreements", Journal of Financial Economics 10 (March, 1982), 59-82.

Kareken, John H. "The Emergence and Regulation of Contingent Commitment Banking", Journal of Banking and Finance, this issue.

Koehn, Michael and Anthony Santomero. "Regulation of Bank Capital and Portfolio Risk", Journal of Finance 35 (December, 1980), 1235-44.

Lucas, Deborah and Robert L. McDonald. "Bank. Financing and Investment Decisions with Asymmetric Information", Finance Department Working Paper, Northwestern University, 1987.

Merton, Robert C. "An Analytic Derivation of the Cost of Deposit Insurance and Loan Guarantees: An Application of Modern Option Pricing Theory", Journal of Banking and Finance, 1 (June, 1977), 3-11.

Myers, Stewart C. and Nicolas Majluf. "Corporate Investment and Financing Decisions When Firms Have Information that Investors do Not Have", Journal of Financial Economics 13, 1984, pp. 187-222.

Poole, William. "Commercial Bank Reserve Management in a Stochastic Model: Implications for Monetary Policy", Journal of Finance 23 (December, 1968), 769-91.

Pyle, David H. "On the Theory of Financial Intermediation" Journal of Finance 26 (June, 1971), 1 737-47.

Santomero, Anthony M. "Modelling the Banking Firm: A Survey", Journal of Money, Credit, and Banking 16 (November, 1984), 576-602.

Sprenkle, Case M. "On the Precautionary Demand for Assets", Journal of Banking and Finance, Vol. 9, No. 4 (December 1985), 499-515.

Thakor, Anjan. "Toward a Theory of Bank Loan Commitments", Journal of Banking and Finance 6 (March, 1982), 55-83. 


\section{Footnotes}

1. In July, 1986, commercial banks in the U.S. held total assets of $\$ 2,537$ billion, of which 25.58 were investment securities and cash assets (Federal Reserve Bulletin, October, 1986, p. Al8).

2. Kareken (1987) presents a model in which the equity requirement has no effect on the probability of bankruptcy. He uses this example to argue that the equity requirement need not be an effective policy tool.

3. In practice, banks must use securities as collateral when borrowing through the discount window. Thus banks would still have a demand for securities even with low cost access to the discount window.

4. The assumption that loan income in period 1 is certain avoids adding uncertainy that would not qualitatively affect the results. The period 1 return is set at a premium over the risk-free rate to capture the fact that if the period 1 return were risky, its truncated return would be above the risk-free rate due to FDIC insurance. In a more complete model, $\alpha_{1}$ would not be fixed, but would be a declining function of the equity-to-asset ratio.

5.The assumption that uncertainty is resolved completely is made for simplicity. The same conclusions would follow if the bank still faced some uncertainty about loan quality, but less than the market.

6. The second argument in the min function is obtained by computing the smallest $\Delta \mathrm{L}_{0}$ which will pay for the withdrawal and substituting this into the equity constraint (4).

7. This restriction has two important effects. Most importantly, it prevents the bank from selling low quality loans and using the proceeds to return deposits in order to slacken the equity constraint. Without this constraint, shareholders could profitably pay themselves large dividends in period 1 when low returns in period 2 are anticipated. Since capital requirements are on the order 58, any liquidation penalty slightly over 58 is sufficient for this condition to hold. This condition also discourages the bank from liquidating old loans that are known to be of low quality and using the proceeds to buy new loans. In equilibrium, one would expect that the discount will be large enough to discourage banks from selling bad loans in order to take a new draw from the loan distribution. However, we assume rather than prove that old loans are not sold in order to buy new loans.

8. To back loans made from new deposits, - g $\delta$ of new equity must be added. We assume that net cash flow at time 1 is sufficiently large so that the shareholders can add this equity simply by foregoing a dividend. For the parameter values used in the simulations, this will always be the case.

9. It should be noted that although the integration boundaries are functions of $S_{0}$, the first order condition does not include derivatives of these terms. This is because the derivatives of integration boundaries are multiplied by expressions which are zero when evaluated at an integration boundary. 
10. The value of the bank may be thought of as a rent from the FDIC insurance. This rent tends to be greatest when loan quality variability is high, but deposit variability is low.

11. A significant difference between loan commitments and deposit withdrawals is that failure to fulfill a loan commitment does not result in bankruptcy. These contracts in fact appear to be frequently renegotiated by both parties. Nevertheless, it may be costly in terms of lost good will and reputation effects for banks to abrogate loan commitments. Even disregarding formal loan commitments, customer relationships are important in banking, and the failure to make a loan on demand could result in a lost customer.

12. This only captures one dimension of the cost to a bank of a loan commitment. For an options pricing approach to pricing loan commitments, see Thakor (1982) and Hawkins (1982).

13. Bank value can be negative because we have not included a loan commitment fee in the model.

14. This ambiuguity is in contrast to the effect of a change in $g$ in portfolio-based models of asset selection, such as Koehn and Santomero (1980). They find that an increase in $g$ unambiguously induces banks to choose riskier assets.

15. All integrals are evaluated between $\hat{\alpha}$ and $\alpha_{\mathrm{H}}$.

16. Detailed proofs of Lemmas $3-5$ are available upon request from the authors. 